\title{
LOW-COST DOMESTIC WASTE WATER TREATMENT AND ANALYSIS
}

\author{
Rasika G. Pande \\ Department of Civil Engineering \\ P.E.S. College of Engineering, \\ Aurangabad, Maharashtra, India.
}

Prof.Alte. P.D.

Department of Civil Engineering

P.E.S. College of Engineering,

Aurangabad, Maharashtra, India.

\author{
Shweta V. Bawaskar \\ Department of Civil Engineering \\ P.E.S. College of Engineering, \\ Aurangabad, Maharashtra, India.
}

\author{
Sayali R. Pardeshi \\ Department of Civil Engineering \\ P.E.S.College of Engineering, \\ Aurangabad, Maharashtra, India \\ Mayur R. Choudhari \\ Department of Civil Engineering \\ P.E.S.College of Engineering, \\ Aurangabad, Maharashtra, India \\ Rutuja P. Mhaske \\ Department of Civil Engineering \\ P.E.S.College of Engineering, \\ Aurangabad, Maharashtra, India.
}

\begin{abstract}
The motive of this paper to prepare some systematic low-priced and sustainable domestic waste water treatment system for household. To acquire this objective we collected samples from the household kitchen sink, basin, laundry etc. From the conclusion we learned that the tested parameters like BOD, COD, TDS, etc. displayed high removal of physical and chemical impurities. The treated water can be used for purposes such as irrigation, car washing, Flushing, etc.
\end{abstract}

Keywords-Low Cost, Domestic waste water, reuse of domestic waste water.

\section{INTRODUCTION}

Water counts as the major resource on Earth. As it is the most essential things that is required by every living being. In order to conserve water some protective measures should be taken. There persist many techniques to save water, but techniques like sand filtration media proves to be low cost for household purpose. Waste water consist of black water and grey water. Grey water is specifically wash water like bath, dish washer, laundry water, it does not conclude toilet water. Yet grey water can be of far higher quality than black water because of its low level of contamination and higher possibility of reuse. The difference between grey water and black water is the organic loading. Grey water also known as Sullage, is nonindustrial waste water mostly generated from domestic operations sometimes even from commercial means. It constitutes about $50 \%$ to $70 \%$ of domestic waste water

We collected water from kitchen, laundry, etc. and passed it through our filter model which consist of layers of earthy materials and tend to be economical. We tested the sample and result came out adequate to be as it satisfied almost all parameters.

Agriculture is the major consumer of water (about $64 \%$ of water demand goes for agricultural uses). So therefore, refinement of grey water and its deployment for agricultural utilization is crucial.

\section{SySTEM DEVELOPMENT}

\section{A] METHODOLOGY}

Domestic waste water methodologies range from simple lowcost devices that divert domestic waste water to direct reuse, such as in toilets or outdoor landscaping, to complex treatment processes incorporating sedimentation tanks, bioreactors, filters, pumps, and disinfection. Some domestic waste water plants are home-built, do-it-yourself style through piping and storage systems.

\section{B] CONSTRUCTION OF OUR MODEL}

\section{Filter Media}

The filter media consists of sand layer about 20 to 30 $\mathrm{mm}$ in depth and placed over a gravel support.

The effective size of sand varies from 0.1 to 0.2 and uniformity coefficient varies from 0.8 to 0.9 .

The coarser layer should be at bottom and finer layer should be at top. Top layer should contain uniform in grain size. 


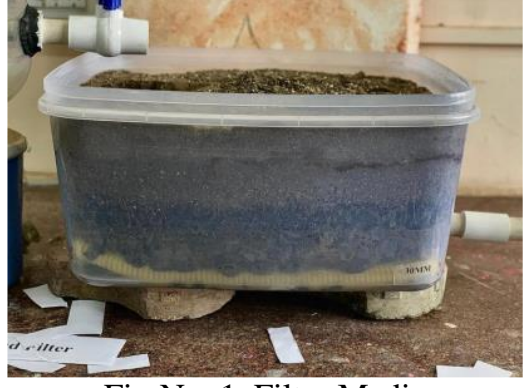

Fig No. 1. Filter Media

\section{Base Material}

The base material is gravel, and it supports the sand. It consists of 1.0 to $1.5 \mathrm{~mm}$ thick, with gravels of different sizes, which placed in 1 layer.

Thickness of each layer around $3 \mathrm{~cm}$ are used.

The coarsest gravel is used in the bottom, most layer and the finest layer is used in the top most layer. The size of each layer is as:

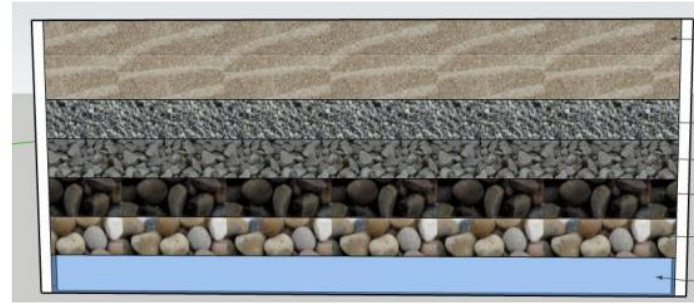

Fig No. 2. Base Material

\section{Under Drainage System}

The gravel support is laid on the top of an under drainage system.

The under drainage system consists of a central and lateral drains.

The lateral are open jointed pipe drains or some other kind of porous drains placed 30 to $50 \mathrm{~mm}$ apart on the bottom floor and sloping towards a main central covered drain.

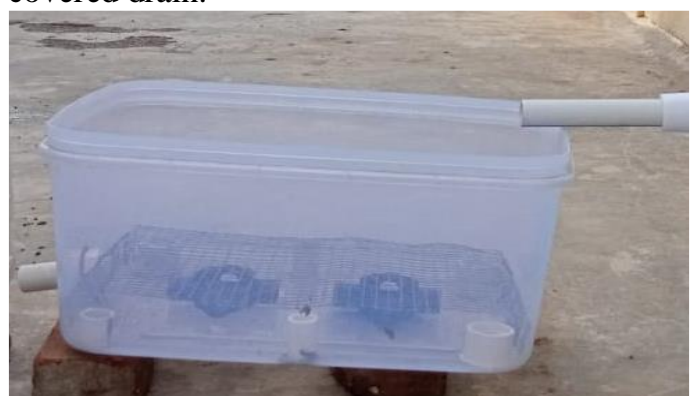

Fig No. 3. under drainage system

\section{Inlet and Outlet arrangements}

An Inlet chamber is constructed for admitting the clarifier's effluent without disturbing the sand layers of the filter and to distribute it uniformly over the filter bed.

Inlet and outlet are generally governed by adjustable valves.

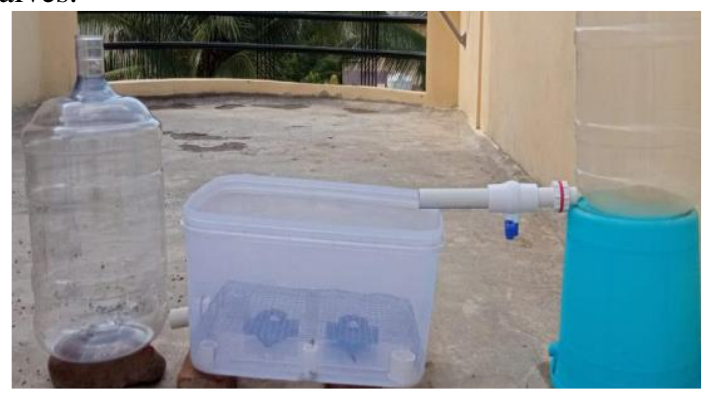

Fig No. 4. Inlet and outlet arrangements

\section{RESULT AND DISCUSSION}

We have performed the various tastes on the domestic waste water for its better implementation which can use for the gardening and flushing. We have taken the domestic waste water sample and passed it through the sand filter.

We have taken 15 liters of waste water for treatment.

And For 14 liters treated water the detention time required is 3 hours.

Tested parameters
\begin{tabular}{|l|l|l|l|}
\hline S.No. & Parameter & $\begin{array}{l}\text { Unfiltered Wample } \\
\text { Sater }\end{array}$ & Filtered Water Sample \\
\hline 1. & PH & 7.06 & 7.44 \\
\hline 2. & Chlorine & $199.93 \mathrm{Mg} / 1$ & $369.88 \mathrm{Mg} / 1$ \\
\hline 3. & SO4 & $183 \mathrm{Mg} / 1$ & $167.0 \mathrm{Mg} / 1$ \\
\hline 4. & Total Dissolved solids & $3546 \mathrm{Mg} / 1$ & $910 \mathrm{Mg} / 1$ \\
\hline 5. & Suspended Solids & $183 \mathrm{Mg} / 1$ & $140 \mathrm{Mg} / 1$ \\
\hline 6. & Oil \& Grease & $55 \mathrm{Mg} / 1$ & $<1 \mathrm{Mg} / 1$ \\
\hline 7. & Chemical Oxygen Demand & $1760 \mathrm{Mg} / 1$ & $400 \mathrm{Mg} / 1$ \\
\hline 8. & Biochemical Oxygen Demand & $520 \mathrm{Mg} / 1$ & $120 \mathrm{Mg} / 1$ \\
\hline
\end{tabular}

Table No. 1. Tested parameters

\section{CONCLUSION}

The present study demonstrate that, reusing of domestic waste water will surely help to resolve the complications of water demand. If we apply and use this type of techniques in every household we can easily conquer the problems about the water demand. Hence this project is very helpful as it is economical, effectual, and organic and inventive for the development of country.

\section{REFERENCE}

[1] A.D. Mande,B R kavathekar, A.S langade, N.G. lasankute, S. H. patle, (2018), - Low Cost Household Water Treatment Systems: A Reviwll, International 
journal of engineering research \& technology (IJERT), ISSN: 2278-0181, Vol. 7 Issue 03.

[2] Indranil Guin, Susheel Kumar Gupta, (2017) — Low Cost Methods of Treatment of Water for Domestic Purposes in Rural Areasll, International journal for scientific research and development, ISSN: 2321-0613, Vol. 4 Issue 12.

[3] S. Gautam, S. Ahmad, A. Dhingra, Z. Fatima, (2017), -Cost-Effective Treatment Technology for Small Size Sewage Treatment Plants in India, journal of scientific and industrial research, Vol. 76, pp.249-254.

[4] EIZein Z, Abdou. A, Abd EL Gawad I. (2016), -Constructed Wetlands As A Sustainable Waste Water Treatment Method In Communities\| (2016) pp, ISSN:605-617 ELSEVIER.

[5] Karnapa Ajit. (2016) -A Review On Greywater Treatment And Reusell, International Research Journal Of Engineering And Technology (IRJET) vol.03 Issue:05, May 2016.

[6] Sameer S. Shastri (2014) -Zero Waste Disposal System for Multi-Storied Building.

[7] Narghessh Amabadi, Hasan Bhaktiari, Nafise Kochakiam, Mahamood Farahani, (2015) - The Investigation and Designing of An Onsite Greywater Treatment System At Hazrat-e-Masoumeh Universityll, Qom, (IRAN) ISSN: 1337-1346.

[8] Sandhya Pushkar Singh, Nusrat Ali, Sabih Ahmad, Dr. J.K. Singh, Manoj Kumar, (2015), -A Study On Greywater Treartment Processes: A Reviewll, International Journal For Scientific Research And Development, ISSN (online): 2321-0613, vol.3, Issue 08.

[9] Prof. K. D. Bhuyar, Mr. Amit. R. Lohakare, Mr. Tejas Patil, Mr. Yogesh Ghode, Ms. Sofiya Sayyad, (2015), - Treatment of Water by Membrane BIO Reactorl, International Journal For Scientific Research \& Development, ISSN: 2321-0613, vol. 2, Issue 12.

[10] Vijaya V Shegaokar et. al. (2015), —Design And Treatability Studies Of Low Cost Grey Water Treatment With Respect To Recycle And Reuse In Rural Areasll. (ISSN): 2319-7706 vol. 4, no.8 (2015) pp. 